\title{
INTER-RELATIONSHIP OF PUNTIUS HAMILTON-BUCHANAN (CYPRINIDAE: CYPRININAE) FOUND IN MANIPUR, INDIA
}

\author{
M. Shantakumar ${ }^{1}$ and W. Vishwanath ${ }^{2}$
}

\author{
1,2 Department of Life Sciences, Manipur University, Canchipur, Imphal, Manipur 795003, India
}

Email: 2 vnath54@yahoo.co.in (corresponding author)

\begin{abstract}
Inter-relationship of 12 species of the genus Puntius Hamilton-Buchanan were investigated based on certain osteological characters. Fishes under study consists of three phylectic groups: sophore, conchonius and sarana. The sophore group is characteristic in having a cranial fontanel; smooth last simple dorsal spine; slender $3+4$ infraorbital; eight predorsal vertebrae and less number of vertebrae, and conchonius group, by absence of barbels; cranial fontanel and in having finely serrated last simple dorsal spine; greatly enlarged 3+4 infraorbital; slender pharyngeal bone with pointed dorsal limb. Sarana group consists of larger sized fishes having less body colour markings; presence of two pairs of well-developed barbels; a pair of uroneurals on the dorsal tip of the urostyle; higher total vertebral counts (35-36) and predorsal vertebral counts (10).
\end{abstract}

KEYWORDS

Inter-relationship, Manipur, osteology, Puntius.

Small freshwater fishes of the genus Puntius HamiltonBuchanan of the family Cyprinidae is represented by a large number of species of Asian tropics. Roberts (1989) described the genus to have the following combination of characters: barbels variable, rostral and maxillary, maxillary only, or absent; dorsal fin with last simple ray serrate or entire, branched rays usually eight; anal fin with last simple ray serrate or entire, branched rays usually five; lateral line complete or incomplete, lateral line scales 17-36; cephalic cutaneous papillae minute or absent; pharyngeal teeth in three rows, usually $2,3,5 / 5,3,2$; colour pattern extremely variable; size ranging from less than 10 to $30 \mathrm{~cm}$.

Puntius is a complex genus, which exhibit high degree of variability in colour pattern, size, and habitat such as lake, ditches, pond, river and hill-stream. The status of Puntius is obscure; the delimitation and nomenclatural validity of the genus have remained unsettled (Hora \& Mukerji, 1934; Smith, 1945; Myers, 1960). Kottelat (1999) described Puntius as a 'catchall' genus in which a large number of unrelated small barbs have been placed, however, restricted to a very limited geographical area and without information on the limits of the genera. Kullander and Fang (2005) mentioned that the obscure status of the group is owing to scantiness in the knowledge of its inter and infrageneric relationship. They also reported the conchonius group of the genus is to be widely distributed in India and Myanmar.

Numerous species of Puntius occur in the Salween, Irrawady and Ganga drainages of the Indian region. Some of them have very similar characters making it difficult to differentiate.
Examination of species inhabiting these rivers is required to elucidate more clearly the lines of differentiation and dispersal of Puntius (Taki et al., 1978). Tremendous diversity of Puntius having 53 species is distributed throughout India, Nepal, Bangladesh, Sri Lanka, Myanmar, Thailand, Malaya Archipelago and southern China (Jayaram, 1991).

As many as 12 species of genus Puntius are found in Manipur, a state in the northeastern corner of India. They are: P. bizonatus Vishwanath and Laisram, $P$. chola Hamilton-Buchanan, $P$. conchonius (Hamilton-Buchanan) P. jayarami Vishwanath and Tombi Singh, P. manipurensis Menon, Rema and Vishwanath, P. ornatus Vishwanath and Laisram, P. orphoides (Valenciennes), P. sarana (Hamilton-Buchanan), P. sophore (HamiltonBuchanan), P. stoliczkanus Annandale, P. terio (HamiltonBuchanan) and P. ticto (Hamilton-Buchanan). In the present study, detailed osteological examination of the 12 species has been carried out and an attempt is made to group and establish interrelationship of the species.

\section{Materials and Methods}

Fresh specimens were collected from different fish landing centres of Manipur. Measurements and counts followed Jayaram (1999). Cleared and stained specimens were used for osteological studies; clearing and staining of specimens followed Hollister (1934). Infraorbital bones were observed in Alizarin stained transparent specimens. Identification of the bones mostly followed Weitzman (1962). The terminology of the circumorbital bone was based on Nelson (1969). In the count of vertebra the fused $\mathrm{PU}_{1}+\mathrm{U}_{1}$ is considered as a single element and the vertebrae incorporated into the Weberian apparatus are counted as four elements.

The species taken up for study were identified based on Hora (1937) for P. stoliczkanus, Jayaram (1991) for P. conchonius, $P$. sophore, P. chola, P. ticto, P. orphoides, P. sarana, P. terio, $P$. jayarami; Menon et al. (2000) for P. manipurensis and Vishwanath and Laisram (2004) for P. bizonatus and P. ornatus.

\section{Results ANd Discussion}

Cranial fontanel: Three species, namely, P. sophore, P. chola and $P$. terio have a prominent dorsomedian cranial fontanel. It is rectangular and elongated extending from middle of parietal to the middle of the frontal (Fig. 1a). The remaining nine species have no cranial fontanel (Fig. 1b).

Dorsal spine: All the species have well developed ossified last dorsal fin spine. It shows two types: smooth and serrated. 


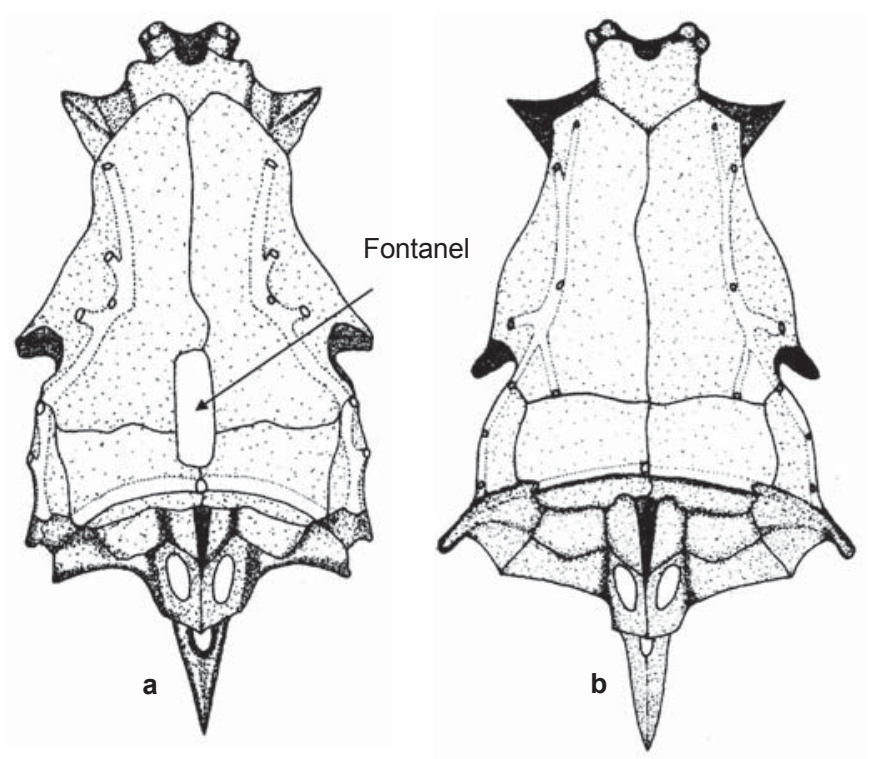

Figure 1. Dorsal view of skull.

$a$ - Puntius orphoides; $b$ - Puntius sophore

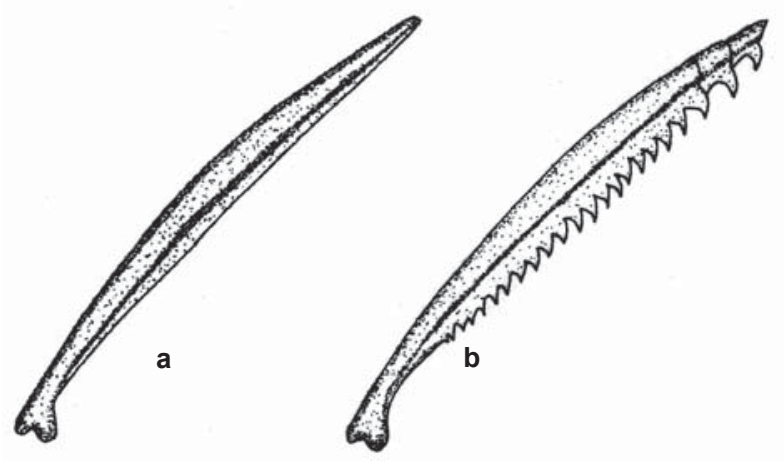

Figure 2. Last simple dorsal spine $a$ - Puntius sophore; $b$ - Puntius conchonius

Weak and smooth spine (Fig. 2a) is found in three species: $P$. sophore, $P$. chola and $P$. terio. The remaining nine species have posteriorly serrated last dorsal spine (Fig. 2b).

Infraorbital series: Infraorbital bone structure varies among the different species. Accordance to Taki (1978), infraorbital series consists of a lachrymal, three infraorbital and one dermosphenotic in most species of Puntius. They also reported that infraorbital 3 and 4 are fused together into a large bone bordering the bottom of the orbit, which they termed as infraorbital $3+4$. Their studies does not include $P$. terio.

Infraorbital series of the fishes under study fall into three types: A (Fig. 3a) and B (Fig. 3b) and C. In A, bone 3+4 is much expanded and the outer margins of remaining elements are also expanded and arched. Such type is found in P. bizonatus, $P$. conchonius, $P$. manipurensis, $P$. ornatus, $P$. stoliczkanus and $P$. ticto. In type $\mathrm{B}$, the infraorbital $3+4$ is only as broad as the remaining bone of the series. $P$. terio has an exceptionally different characteristic. The infraorbital series consists of a a

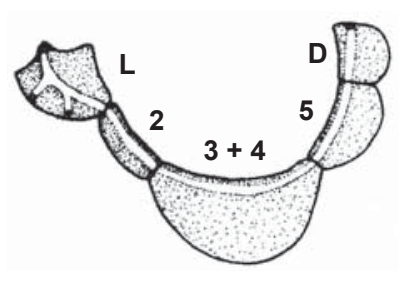

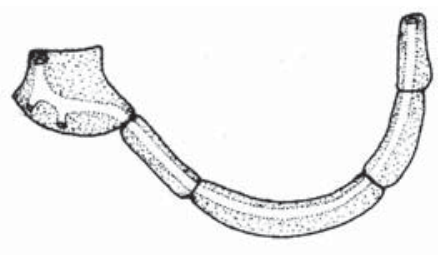

Figure 3. Infraorbital bones of Puntius $a$ - Puntius conchonius; $b$ - Puntius sophore; L - lacrimal; 2-5 - infraorbitals; D - dermosphenotic

lachrymal and three infraorbital bones, but the dermosphenotic is missing. The fifth infraorbital is thin pore bearing bone, much elongated, so that it extends up to the area of the dermosphenotic. This condition is regarded as type $\mathrm{C}$ here.

Dentary: The dentary have well developed, high coronoid process in all species. There are variations in the position and shapes of coronoid process in different species. There are two types, A (Fig. 4a), which is thin and long with a slender, high, posteriorly directed coronoid process situated in the middle of the dentary. P. chola, P. jayarami, $P$. orphoides, $P$. sarana, $P$. sophore and $P$. terio fall in this type. In B (Fig. 4b), dentary is short, stout, broad and curved with well developed, broad coronoid process. Posterior margin of the coronoid process extends almost up to the posterior edge of the dentary. $P$. conchonius, P. ticto, P. manipurensis, P. ornatusatus, $P$. bizonatus, $P$. stoliczkanus are of this type.
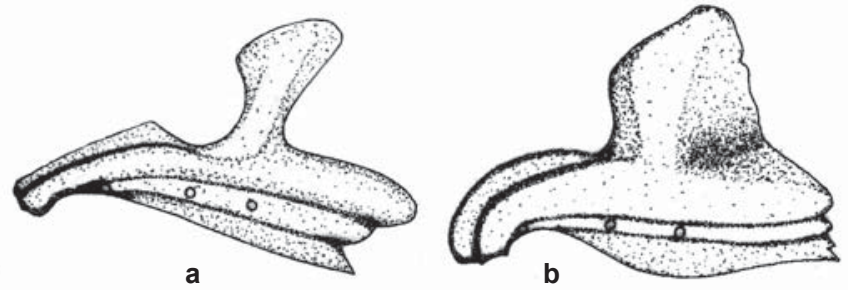

Figure 4. Dentary of Puntius

a - Puntius chola; $b$ - Puntius conchonius

Predorsal vertebral counts and supraneurals: A series of midsagital ossification are found dorsal of the vertebral column in the region between the rear of the neurocranium and the anterior most proximal radial pterygiophore of the dorsal fin. These bones, the supraneurals along with proximal radial pterygiophores of the dorsal fin interdigitate basally between the distal portions of the neural spines of the proximate vertebrae. There are four to six supraneurals in Puntius.

The predorsal vertebral count shows two features i.e. eight and 10 with nine as the intermediate between the two counts. The $1^{\text {st }}$ supraneural is located anterior to neural spine of the $5^{\text {th }}$ vertebra. P. sophore, $P$. chola, $P$. terio, P. conchonius, $P$. stoliczkanus, $P$. ornatus and $P$. bizonatus have only four supraneurals and eight predorsal vertebral counts. $P$. manipurensis have five supraneurals and nine predorsal 
vertebrae. $P$. jayarami, $P$. sarana and $P$. orphoides have six supraneurals and 10 predorsal vertebrae.

Vertebral counts: The number of vertebrae ranges from 29-36 in different Puntius species. The number is inclusive of the first four vertebrae of the complex vertebra and the last fused pre-ural and ural centrum. In small species like $P$. sophore, $P$. chola, $P$. terio, $P$. conchonius, etc., vertebral counts are less compared to larger species like $P$. sarana, $P$. orphoides, and $P$. jayarami.

The total vertebral count ranges from $35-36$ in $P$. sarana group, 29-33 in $P$. conchonius and $P$. sophore groups.

Caudal fin: The last three caudal vertebrae support the caudal fin. There are six hypurals and one parhypural. None of the hypurals are expanded. The $5^{\text {th }}$ and $6^{\text {th }}$, hypurals are very small. There is an epural above the specialized neural process (Terminology of Hollister, 1936) and anterior of the urostyle. The parhypural bears a hypurapophysis at the base.

Caudal fin of Puntius has $10+9$ principal rays. In addition, there are also three unsegmented rays and four segmented procurrent rays dorsally, and three segmented and three unsegmented procurrent rays ventrally. There is not much variation in the structure of the caudal fin among the different species of Puntius.

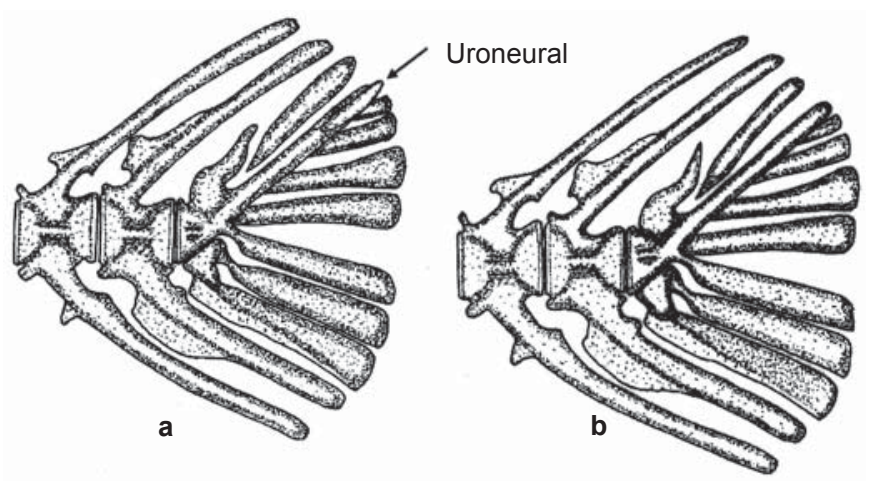

Figure 5. Caudal skeleton

a - with uroneural; b - without uroneural

There is a pair of small uroneurals attached on the dorsolateral side of the urostyle. Its one end is connected to distal end of urostyle and another end extends little beyond urostyle and in between the first and second principal rays. The left and right uroneurals are not fused. Wietzman (1962) called such structure as uroneurals. Roberts (1969) also reported the presence of such structure in Salminus which termed as 'ossified ligament'. Chen and Chen (2001) also reported presence of uroneurals in Schizothorax kozlovi, S. wangchia and S. lissolabi. Uroneurals (or ossified ligament) (Fig. 5a) is present only in four species, namely, $P$. orphoides, $P$. sarana and $P$. jayarami. The uroneurals are absent in all the remaining Puntius species under study (Fig. 5b).
Barbels: There is variation in the number of barbels among the different species of Puntius. Barbels are missing in P. sophore, $P$. terio, P. conchonius, $P$. stoliczkanus, $P$. ornatusatus, $P$. bizonatus, $P$. ticto and P. manipurensis. $P$. chola has only one pair of barbels and $P$. jayarami, $P$. sarana and $P$. orphoides have two pairs. Two types are recognized: type A, with only one pair or no barbels and type B, with two pairs of barbels.

Colour: Puntius have different black body markings, whose shapes and sizes are variable depending on the physiological state, stage of maturity and season. Some species have beautiful colour patterns. The black body markings are named according to their position, i.e., pectoral (PC), post anal (PA) and caudal (CD) markings (Fig. 6). Five different types of colour patterns are recognized. They are, type A: body plain or with a caudal blotch which tends to fade with growth; type B: body with rounded or vertically elongated spots at the post anal and one above the pectoral; type $\mathrm{C}$ : body with a vertically elongated black marking at the post anal region; type D: a modified form of $\mathrm{C}$ in which a fine dark line running from the post anal spot to the caudal base; and type E: body with a distinct rounded caudal blotch.

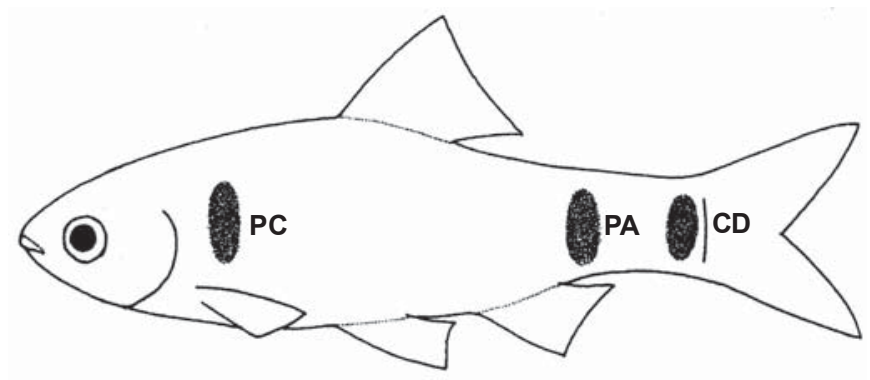

Figure 6. Different body markings in Puntius PC - Pectoral marking; PA - Postanal marking; $C D$ - Caudal marking
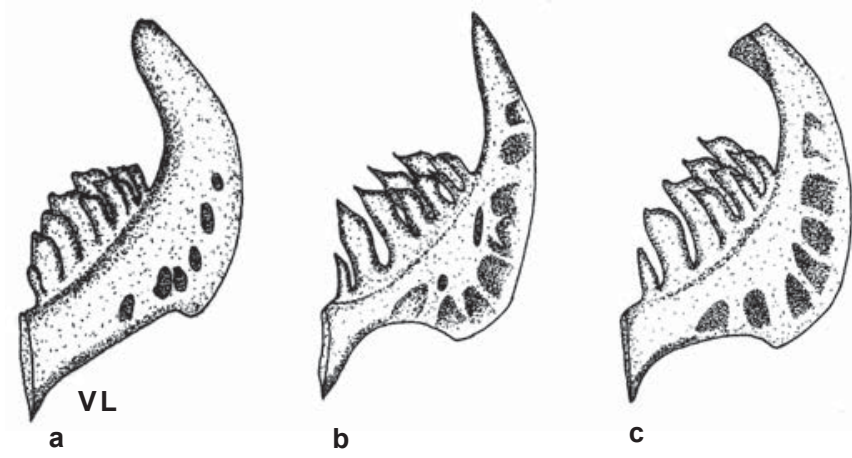

Figure 7. Types of pharyngeal bone in Puntius $a$ - Puntius orphoides; $b$ - Puntius conchonius; c - Puntius sophore

Pharyngeal bone and teeth: All of the 12 species have three rows of pharyngeal teeth. The outer or the first row has two slender teeth; second or the middle row has three teeth and the last or the inner main row has five large, broad teeth. There are 
not many variations in the pharyngeal teeth formula except for some difference in the structure of the teeth. Depending on the structure, there are three types of pharyngeal bones (Figs. 7a, b \& c). They are type A: pharyngeal bone broad, stout, dorsal limb broad with truncate tip, vertical limb short; type B: pharyngeal bone narrow, long, dorsal limb sharply or bluntly pointed; and type $\mathrm{C}$ : pharyngeal bone broad, tip of the dorsal limb blunt, expanded, recurved in and forward.

\section{Discussion}

The morphological and osteological comparison of the present 12 species examined indicates that they constitute three phylectic groups each consisting of species sharing these morphological features almost completely. The three groups are sophore group, conchonius group and jayarami group. The morphological similarity as seen among species in each group is sufficient to suggest that members of the same group are descendants from a common direct ancestral stock. The members of the sophore group differentiated from other groups in having a cranial fontanel; smooth last simple dorsal spine; slender 3+4 infraorbital; absence of barbels except $P$. chola where a pair of barbel is present; eight predorsal vertebrae, a distinct pharyngeal bone type $\mathrm{C}$ and low total vertebral counts. Although $P$. terio lacks a dermosphenotic, it is for the time being placed in the sophore group. It needs further investigation.

The characters of six species of conchonius group are in complete agreement in the characteristics of the group. They are small-sized, beautifully coloured fishes. In contrast to the other two groups barbels are completely absent; last simple dorsal spine finely serrated; infraorbital $3+4$ greatly enlarged covering most of the cheek region; pharyngeal bone slender with pointed dorsal limb and eight predorsal vertebra except for $P$. manipurensis in which there are nine. Eight numbers of predorsal vertebrae seems to be the most common count in Puntius (9 out of 12 species examined). This state seems to be the plesiomorph condition in the Puntius under study.
Sarana group is larged-sized fishes which differ from others in having comparatively less body colour markings, presence of two pairs of well-developed barbels, a pair of uroneurals on the dorsal tip of the urostyle, higher total vertebral counts than smaller species (35-36 vs. 29-33). Mirza and Abdussamad (1982) reported higher vertebral counts in the sarana group than other species $(36$ vs. $<30)$ and are of the opinion that $P$. sarana belongs to a different stock. The predorsal vertebral counts also increase from the smaller species to larger species (from 4 to 6) i.e., from sophore group to sarana group. The number of vertebrae is within certain limits often characteristic of a given species or at least genus (Harder, 1975). Bailey and Gosline (1955) reported certain differences in the vertebral counts between genera and most subgenera and between many species within a subgenus. The analysis of these differences indicates vertebral numbers to be a powerful adjunct to phylogenetic interpretation in the American percids.

The placement of $P$. sophore, $P$. terio, $P$. conchonius and $P$. ticto in one group by Jayaram (1991) contradicts our present findings. Osteological studies reveal that $P$. conchonius and $P$. ticto fall under conchonius group where cranial fontanel is absent while $P$. sophore and $P$. terio fall under sophore group where cranial fontanel is present. Taki et al. (1978) also reported based on osteological study that $P$. conchonius and $P$. sophore belonged to different stocks.

The present observations resulting in the placement of $P$. sarana and $P$. sophore under two groups also supports the idea of Jayaram (1991) who suggested independent evolution of the two species from different stocks. Larger Puntius species i.e. $P$. sarana, $P$. jayarami and $P$. orphoides group is quite distinct group from the smaller beautifully coloured Puntius species.

\section{REFERENCE}

Bailey, R.M. and W.A. Gosline (1955). Variation and systematic significance of vertebral counts in the American fishes of the family Percidae. Miscellaneous Publications Museum of Zoology, University of Michigan 93: 1-44.

Table1. Osteological characteristics of 12 Puntius species.

\begin{tabular}{|c|c|c|c|c|c|c|c|c|c|c|c|c|}
\hline Group & Species & Fontanel & Barbel & $\begin{array}{l}\text { Last simple } \\
\text { dorsal spine }\end{array}$ & $\begin{array}{l}\text { Infraorbital } \\
3+4\end{array}$ & $\begin{array}{l}\text { No. of } \\
\text { supran- } \\
\text { eurals }\end{array}$ & $\begin{array}{l}\text { No. of } \\
\text { predorsal } \\
\text { vertebra }\end{array}$ & $\begin{array}{l}\text { No. of } \\
\text { vertebra }\end{array}$ & $\begin{array}{l}\text { Uro- } \\
\text { neural }\end{array}$ & $\begin{array}{l}\text { Phary- } \\
\text { ngeal } \\
\text { bone }\end{array}$ & $\begin{array}{l}\text { Colour } \\
\text { Pattern }\end{array}$ & Dentary \\
\hline \multirow[t]{3}{*}{ sophore } & Puntius sophore & + & A & smt & $\sin$ & 4 & 8 & $\begin{array}{l}26+4 \\
\text { (complex } \\
\text { vertebra) }\end{array}$ & - & A & A & A \\
\hline & Puntius chola & + & $A$ & smt & $\sin$ & 4 & 8 & $26-29+4$ & - & A & A & A \\
\hline & Puntius terio & + & A & smt & $\sin$ & 4 & 8 & $26+4$ & - & A & $\mathrm{D}$ & A \\
\hline \multirow[t]{6}{*}{ conchonius } & Puntius conchonius & - & $A$ & srt & brd & 4 & 8 & $25-26+4$ & - & B & $\mathrm{B}$ & $\mathrm{B}$ \\
\hline & Puntius stoliczkanus & - & $A$ & srt & brd & 4 & 8 & $25-26+4$ & - & B & $\mathrm{B}$ & $\mathrm{B}$ \\
\hline & Puntius ornatus & - & A & srt & brd & 4 & 8 & $26-27+4$ & - & B & $\mathrm{C}$ & $\mathrm{B}$ \\
\hline & Puntius bizonatusi & - & A & srt & brd & 4 & 8 & $26-28+4$ & - & B & B & $\mathrm{B}$ \\
\hline & Puntius ticto & - & $A$ & srt & brd & 5 & 8 & $27-29+4$ & - & B & $\mathrm{B}$ & $\mathrm{B}$ \\
\hline & Puntius manipurensis & - & A & srt & brd & 5 & 9 & $26-27+4$ & - & B & $\mathrm{B}$ & $\mathrm{B}$ \\
\hline \multirow[t]{3}{*}{ sarana } & Puntius sarana & - & B & srt & $\sin$ & 6 & 10 & $32+4$ & + & C & $\mathrm{E}$ & A \\
\hline & Puntius orphoides & - & $\mathrm{B}$ & srt & sln & 6 & 10 & $31+4$ & + & $\mathrm{C}$ & $\mathrm{E}$ & A \\
\hline & Puntius jayarami & - & B & srt & sln & 6 & 10 & $31+4$ & + & C & $\mathrm{E}$ & A \\
\hline
\end{tabular}

+ - present; - - absent; brd - broad; sln - slender; smt - smooth; srt - serrated 
Key to Puntius and related species of Manipur

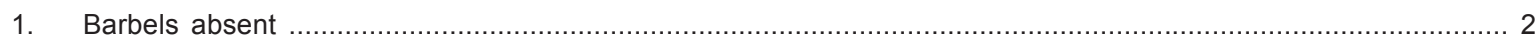

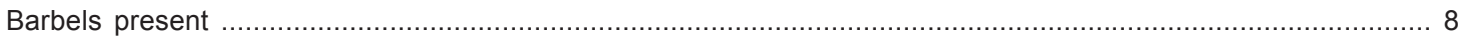

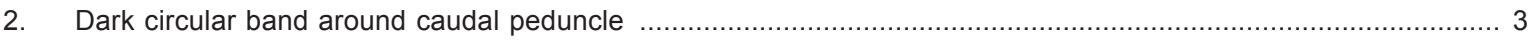

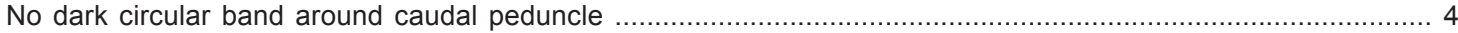

3. One black band forming a ring around caudal peduncle ............................................................... P. ornatus One black band forming a ring around caudal peduncle and one transverse band on $3^{\text {rd }}-4^{\text {th }}$ scale $\ldots \ldots . . . . P$. bizonatus

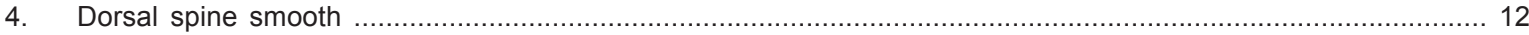

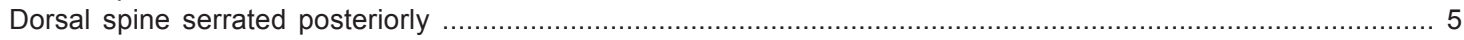

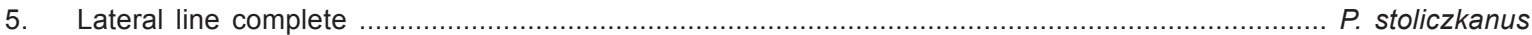

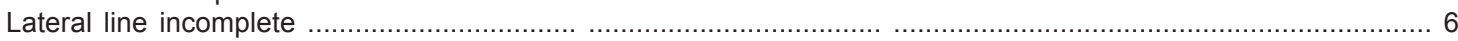

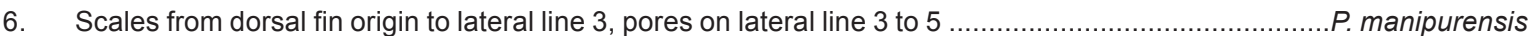

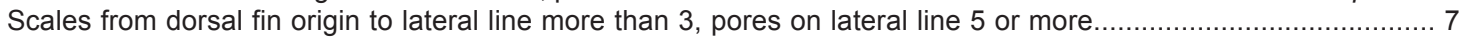

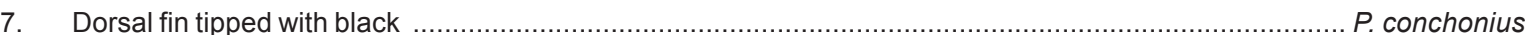

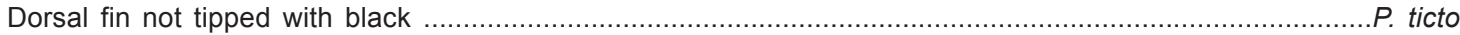

8. Barbels 1 pair, body marked with two conspicuous dark blotches, first behind operculum and second near base of

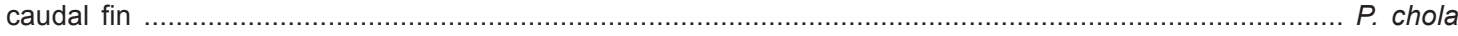

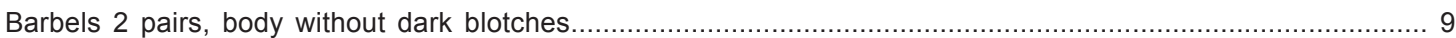

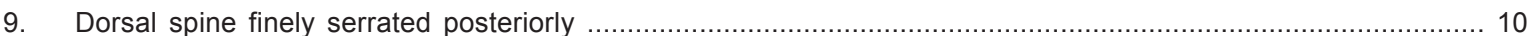

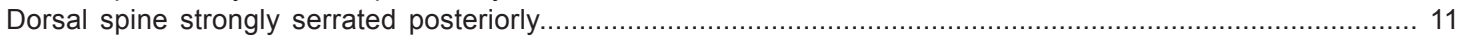

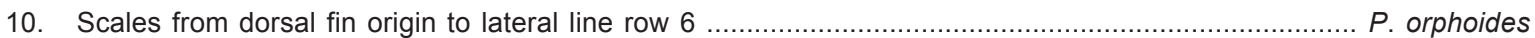

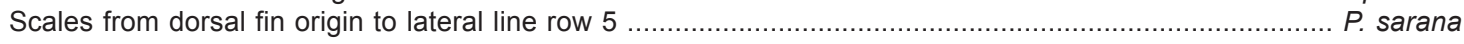

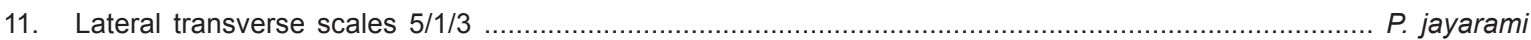

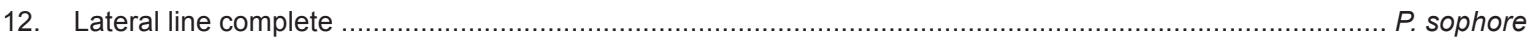

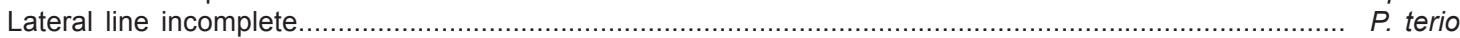

Chen, Z.M. and Y.F. Chen (2001). Phylogeny of the specialized Schizothoracine fishes (Teleostei: Cypriniformes: Cyprinidae). Zoological Studies 40(2): 147-157.

Hamilton, F. (1822). An Account of the Fishes Found in the River Ganges and its Branches. Edinburgh, viii $+405 \mathrm{pp}, 39 \mathrm{pls.}$

Harder, W. (1975). Anatomy of fishes. Part I. E. Schweizerbart' sche Verlagsbuchhandlung. Stuttgart, 611pp.

Hollister, G. (1934). Clearing and dying fishes for bone study. Zoologica 12: 89-101.

Hollister, G. (1936). Caudal skeleton of Bermuda shallow water fishes. 1. Order Isospondyli: Elopidae, Megalopidae, Albulidae, Clupeidae, Dussumeiriidae, Engraulidae. Zoologica 21: 257-290.

Hora, S.L. (1937). Notes on fishes in the Indian Museum. Records of the Indian Museum 39: 321-350.

Hora, S.L. and D.D. Mukerji (1934). Notes on fishes in the Indian Museum, xxiii. On a collection of fishes from S. Shan states, Burma. Records of the Indian Museum 36: 353-370, 1-3figs.

Jayaram, K.C. (1991). Revision of the genus Puntius Hamilton from the Indian region (Pisces: Cypriniformes: Cyprinidae: Cyprininae). Occasional Paper, Records of the Zoological Survey of India 135: 178. Jayaram, K.C. (1999). The Freshwater Fishes of the Indian Region. Narendra Publication, Delhi, 551pp + 18pls.

Kottelat, M. (1999). Nomenclature of the genera Barbodesi, Cyclocheilichthys, Rasbora and Chonerhinos (Teleostei: Cyprinidae and Tetraodontidae), with comments on the definition of the first reviser. Raffles Bulletin of Zoology 47(2): 591-600.

Kullander, S.O. and F. Fang (2005). Two new species of Puntius from Northern Myanmar (Teleostei: Cyprinidae). Copeia 2005(2): 290302.

Menon, A.G.K., K. Rema Devi and W. Vishwanath (2000). A new species of Puntius (Cyprinidae: Cyprininae) from Manipur, India. Journal of the Bombay Natural History Society 97(2): 263-268.

Mirza, M.R. and D. Abdumassad (1982). A contribution to the fishes of the genus Puntius Hamilton-Buchanan (Pisces: Cyprinidae) from Pakistan. Biologia 28(1): 61-81.
Myers, G.S. (1960). Preface to any future classification of the cyprinid fishes of the genus Barbus. Stanford Ichthyological Bulletin 7(4): 212215.

Nelson, G.S. (1969). Infraorbital bones and their bearing on the phylogeny and geography of osteoglossomorph fishes. American Museum Novitates 2394: 1-37, 1-22figs.

Roberts, T.R. (1969). Osteology and relationships of Characid fishes, particularly the genera Hepsetus, Salminus, Hoplias, Ctenolucius and Acestrorhynchus. Proceedings of Californatusia Academy of Science 36(15): 391-500, 60figs.

Roberts, T.R. (1989). The freshwater fishes of western Bornatuseo (Kalimantan, Barat, Indonesia). Memoirs of California Academy of Science 14: 1-210.

Smith, H.M. (1945). The fresh-water fishes of Siam or Thailand. Bulletin of U.S. Natural Museum 188: i-xi, 1-622, 1-107figs, 1-3pls.

Taki, Y., A. Katseyama and T. Urushido (1978). Comparative morphology and interspecific relationship of Cyprinid genus Puntius. Japanese Journal of Ichthyology 25(1): 1-8.

Vishwanath, W. and J. Laisram (2004). Two new species of Puntius Hamilton-Buchanan (Cypriniformes: Cyprinidae) from Manipur, India, with an account of Puntius species from the state. Journal of the Bombay Natural History Society 101(1): 130-137.

Weitzman, S.H. (1962). The osteology of Brycon meeki, a generalized Characid fish, with an osteological definition of the family. Stanford Ichthyological Bulletin 8(1): 1-77.

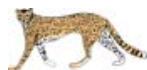

